\title{
Amino-acid absorption by developing herring eggs
}

\author{
D. Siebers \& H. Rosenthal \\ Biologische Anstalt Helgoland (Zentrale); \\ Hamburg 50, Federal Republic of Germany
}

\begin{abstract}
C}-$ glycine absorption by eggs of the herring Clupea harengus from a $2 \mu \mathrm{M}$ solution at $15^{\circ} \mathrm{C}$ depends on the stage of embryonic development. Unidirectional ${ }^{14} \mathrm{C}$-glycine influx rates are small at early stages: $0.6 \pm 0.1$ and $0.5 \pm 0.1$ pmoles egg $^{-1} \mathrm{~h}^{-1}$ in embryos $5 \mathrm{~h}$ and $28 \mathrm{~h}$ after fertilization, respectively. They increase drastically about $51 \mathrm{~h}$ after fertilization

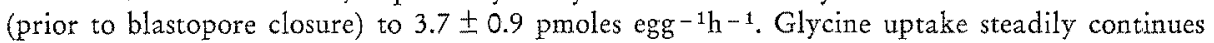

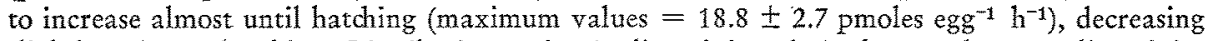
slightly prior to hatching. Distribution ratios (radioactivity $\mu l^{-1}$ of egg volume: radioactivity $\mu \mathrm{L}^{-1}$ ambient medium) exceed the equilibrium ratio of 1 between $51 \mathrm{~h}$ and $78 \mathrm{~h}$ after ferrilization, reaching values of 4.7 two days prior to hatching, thus suggesting the presence of a transport mechanism capable of transferring the amino acid against the concentration gradient. Curves for concentration-dependent ${ }^{14} \mathrm{C}$-glycine and ${ }^{14} \mathrm{C}$-a-aminoisobutyric acid absorption are very similar; they consist of a linear portion at higher concentrations and a saturable component, indicating a mediated uptake process. Calculations performed by means of aminoacid absorption rates and $\mathrm{O}_{2}$ uptake data suggest that herring eggs scarcely obtain nutritional benefits from absorption of dissolved amino acids in natural spawning areas.
\end{abstract}

\section{INTRODUCTION}

The ability of soft-bodied marine invertebrates to absorb low molecular weight organic compounds across their body surface from trace amounts present in sea water against concentration gradients of several orders of magnitude has been demonstrated for members of nearly all phyla according to their availability and experimental suitability (Jørgensen, 1976). Whether marine invertebrates actually obtain nutritional profit from these absorption processes is still a matter of recent discussion (Stephens, 1975; Sepers, 1977).

To the authors' knowledge there is as yet no indication of such absorption processes occurring in fish eggs. As a first approach to this problem an analysis of aminoacid uptake by herring eggs was undertaken. Mass incubation of artificially fertilized eggs from Baltic spring-spawning herring, Clupea harengus, under controlled laboratory conditions provided sufficient egg material for studies on absorption of glycine at different developmental stages. In addition, the concentration dependent uptake of glycine and $\alpha$-aminoisobutyric acid and the specificity of the glycine absorption mechanism were investigated. 


\section{MATERIAL AND METHODS}

Running herring males and gravid females were obtained from catches of local Baltic fishermen. Transport from the catching area to the laboratory and stripping, fertilization, and rearing procedures were identical to earlier published methods (Rosenthal, 1968; Rosenthal \& Stelzer, 1970). The eggs were fertilized on April 4, 1977 , and reared at constant temperature and salinity conditions $\left(12.5^{\circ} \mathrm{C}, 21.9 \% \mathrm{~S}\right)$.

For experiments on amino-acid absorption 25 eggs adhering in single files to small $(6 \times 6 \mathrm{~cm})$ glass plates were thoroughly freed from debris and separated under a dissecting microscope. Thereafter they were transferred into glass vials of $20 \mathrm{ml}$ volume filled with rearing water. Only 15 eggs per sample were used at later stages (from closure of blastopore onward), when glycine uptake rates had increased considerably.

After temperature equilibration $\left(15^{\circ} \mathrm{C}\right)$ the rearing water was carefully removed from the egg-samples and replaced by $5 \mathrm{ml}$ of experimental sea water $(20 \% \mathrm{~S})$, containing 10-750 nmoles of glycine or a-aminoisobutyric acid (AIB), including $50 \mathrm{nCi}$ of uniformly labeled ${ }^{14} \mathrm{C}$-glycine or $\left[1-{ }^{14} \mathrm{C}\right]$ AIB (Amersham). In experiments concerning the specificity of the glycine uptake system, $5 \mathrm{ml}$ of experimental sea water contained 50 nmoles of glycine, including $50 \mathrm{nCi}$ of ${ }^{14} \mathrm{C}$-label, and additionally 500 nmoles of non-radioactive L-alanine, L-valine, L-aspartic acid, or L-arginine.

For direct comparison of glycine uptake between herring eggs and a member of the invertebrate fauna $7-8$ specimens $(25 \mathrm{mg}$ fresh weight) of the oligochaete annelid Encbytraeus albidus were incubated under conditions identical to those applied to the herring eggs. Further experimental details on amino-acid uptake by E. albidus are given by Siebers (1976) and Siebers \& Bulnheim (1976).

All experiments lasted $0.5 \mathrm{~h}$ and were terminated by removal of water and rinsing the incubated material twice with sea water $\left(20 \% 0 \mathrm{~S}, 15^{\circ} \mathrm{C}\right)$. Repeated treatment did not change the amount of absorbed label. After transferring the eggs or worms to counting vials they were deep frozen at $-25^{\circ} \mathrm{C}$.

Counting of absorbed label was performed in a Tracerlab liquid scintillation counter with quench corrections by internal standard after solubilizing animal material for $1.5 \mathrm{~h}$ at $60^{\circ} \mathrm{C}$ in soluene-350 (Packard) and addition of $10 \mathrm{ml}$ of counting solution $\left(5 \mathrm{~g}\right.$ PPO $+0.3 \mathrm{~g}$ POPOP $1^{-1}$ of toluol). For about $10 \%$ of samples $200 \mu 1$ of experimental water were used to calculate the amount of radioactive amino acids available to eggs or worms. In these cases $500 \mu \mathrm{l}$ of distilled water and $10 \mathrm{ml}$ InstaGel (Packard) were added before counting. All investigations were run with 3-7 replicates. Differences in absorption rates between varying experimental conditions were analyzed by means of the t-test.

For uptake experiments natural sea water taken from an area near the island of Helgoland (German Bight, North Sea) was diluted with distilled water to a salinity of $20 \%$ and permanently filtered in circuit in the dark. Immediately before experimental use it was ultrafiltered. Total dissolved amino acids were measured fluorometrically with the fluorescamine reagent (North, 1975; Stephens, 1975). Concentrations ranged from nearly undetectable to about $50 \mathrm{nM}$. 


\section{RESULTS \\ Glycine absorption during the embryonic development}

Absorption of dissolved glycine from ambient sea water by herring eggs depends on the ontogenetic stage of the embryo. Uptake rates are small during the first day

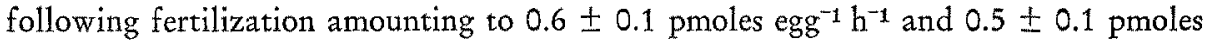
$\mathrm{egg}^{-1} \mathrm{~h}^{-1}$ when exposed $5 \mathrm{~h}$ and $28 \mathrm{~h}$ after fertilization, respectively (Fig. 1). They drastically increase shortly before blastopore closure (51 h after fertilization) with an uptake rate of $3.7 \pm 0.9$ pmoles $\mathrm{egg}^{-1} \mathrm{~h}^{-1}$, indicating a switch-on of absorptive capacities. This increase steadily continues until just prior to hatching, reaching values of $18.8 \pm 2.7$ pmoles egg $^{-1} \mathrm{~h}^{-1}$ at an embryo age of $230 \mathrm{~h}$ after fertilization. Immediately before hatching, however, a decline becomes obvious. Absolute values (pmoles $\mathrm{egg}^{-1} \mathrm{~h}^{-1}$ ) at a given external glycine concentration and temperature - salinity regime seem to be specific for an attained developmental stage. All data in Figure 1 except those presented in broken lines refer to eggs from one single female. Eggs from a second female, which had been reared at $5^{\circ} \mathrm{C}$ for 1 week in order to retard embryonic development, were transferred to rearing temperatures of $12.5^{\circ} \mathrm{C} 2$ days prior to glycine uptake analysis. Absorption rates were found almost identical to those of the first group, when compared to eggs of the same embryonic stage.

The concentration of ${ }^{14} \mathrm{C}$-glycine within the egg volume relative to its exogenous concentration was 0.9 and 1.9 in eggs $51 \mathrm{~h}$ and $78 \mathrm{~h}$ after fertilization, respectively. The last figure exceeds the equilibrium factor of 1 , allowing the assumption of a transport mechanism capable of transferring the amino acid against a concentration gradient. In Figure 1 these values are presented as distribution ratios (radioactivity egg $^{-1}$ : radioactivity $\mu \mathrm{l}^{-1}$ incubation medium after $0.5 \mathrm{~h}$ of uptake), taking an egg volume of about $1 \mu \mathrm{l}$ as calculation basis. Distribution ratios steadily increase during the embryonic development, reaching a final value of 4.7 two days prior to hatching.

\section{Glycine and $\alpha$-aminoisobutyric acid uptake $\mathrm{k}$ ine $\mathrm{tics}$}

The time course of ${ }^{14} \mathrm{C}$-glycine uptake from $2 \mu \mathrm{M}$ solution is shown in Figure 2. Absorption rates are linear with time up to an exposure time of $30 \mathrm{~min}$, beyond which uptake tends to level off. Glycine uptake in relation to ontogenetic stage (see preceding paragraph) was measured at a constant exogenous concentration of $2 \mu \mathrm{M}$, which is regarded to be close to total amino-acid concentrations in coastal areas (cf. Jørgensen, 1976; Sepers, 1977). To obtain information on absorption kinetics of glycine and the non-metabolizable analogue $\alpha$-aminoisobutyric acid, concentration dependent uptake experiments were performed at two embryonic stages (Fig. 3).

While from curve $A(5 \mathrm{~h}$ after fertilization, after few cleavages) concentration dependency is obvious, curves $B$ (glycine) and $\mathrm{E}$ (AIB) (155 h after fertilization, with beginning eye pigmentation) reveal the biphasic nature of amino-acid uptake, 


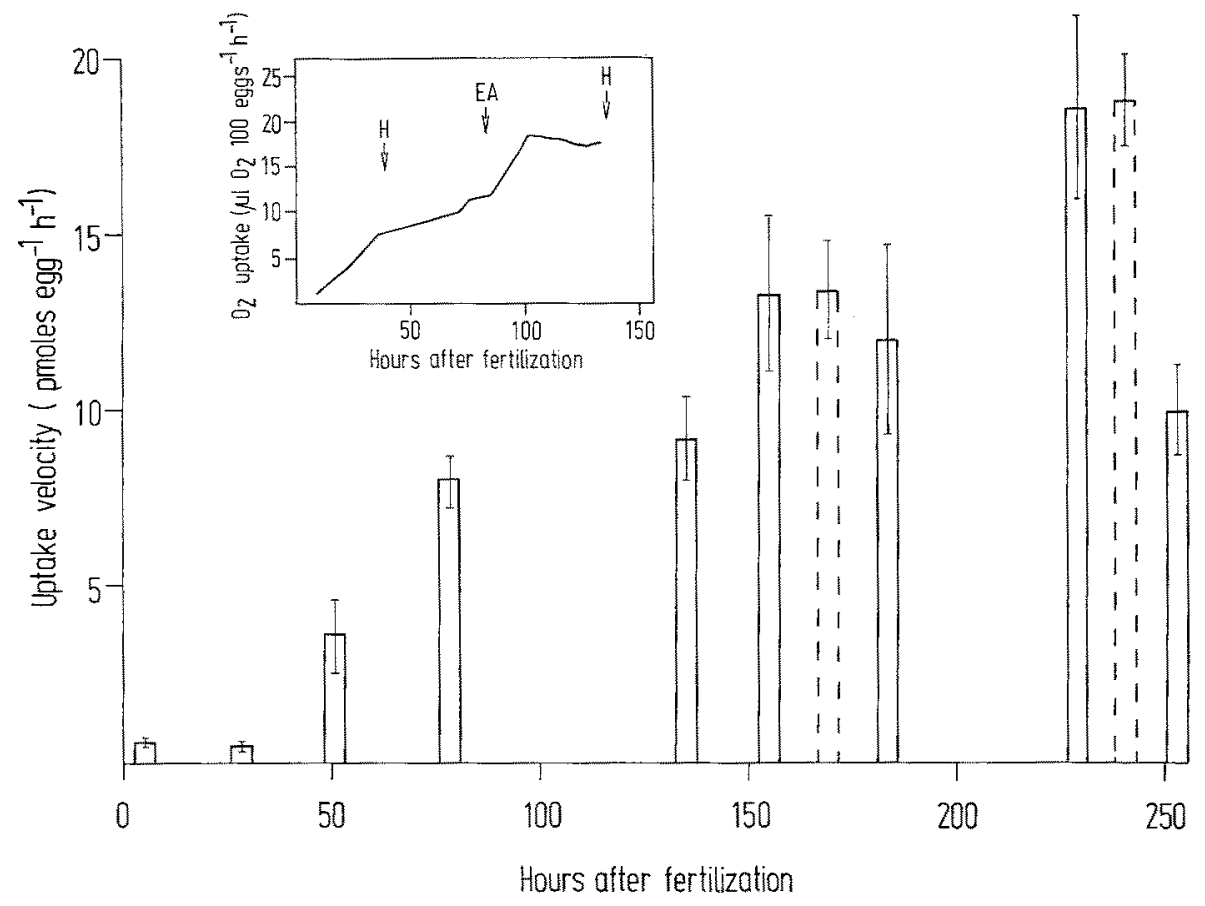

$\begin{array}{lllllllllll}0.2 & 0.1 & 0.9 & 1.9 & 2.3 & 3.3 & 3.3 & 3.0 & 4.6 & 4.7 & 2.4\end{array}$

Distribution ratios

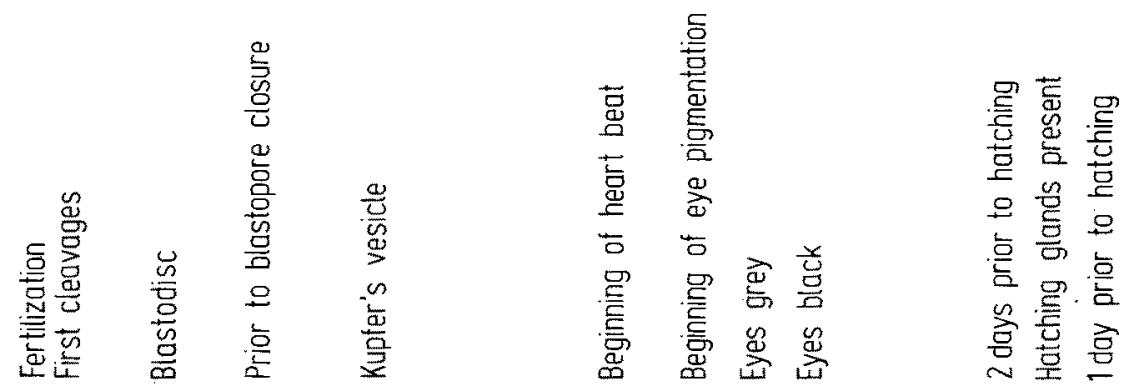

Developmental stage

Fig. 1: Uptake of glycine by developing herring eggs $\left(\mathrm{c}_{\mathrm{gly}}=2 \mu \mathrm{M}, \mathrm{t}=15^{\circ} \mathrm{C}, \mathrm{S}=20 \%\right.$, $\mathrm{n}=5$ ). All data refer to eggs obtained from the same female except those presented in broken columns. In these cases fertilized eggs were kept at $5^{\circ} \mathrm{C}$ to retard embryonic development until 2 days prior to the experiment. The insert (modified and redrawn from Stelzer et al., 1971) refers to $\mathrm{O}_{2}$ consumption of herring eggs $\left(t=14^{\circ} \mathrm{C}, \mathrm{S}=15 \%\right)$ in relation to age $(\mathrm{H}=$ beginning of heart activity, $\mathrm{E}=$ beginning of eye pigmentation, $\mathrm{A}=$ embryonic activity due to increasing rotation of the embryo, $\mathrm{H}=$ hatch) 
being curvilinear up to about $15 \mu \mathrm{M}$ and linear above this ambient concentration. This indicates the presence of at least two separate amino-acid uptake systems. The first operates at lower concentrations and reveals saturation kinetics. The second one, which operates at higher concentrations, is linear in relation to ambient concentrations. The curves presented in Figure $3(\mathrm{~B}, \mathrm{E})$ do not reveal whether the nonsaturable component results from simple diffusion or belongs to a second facilitated system which is non-saturable within the applied concentration range. The rates

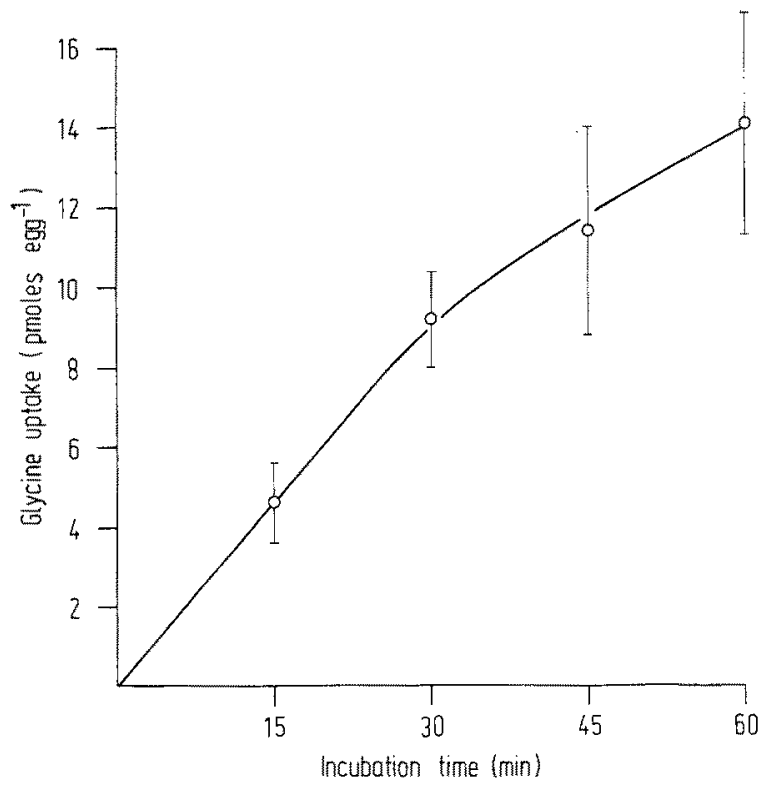

Fig. $2:{ }^{14} \mathrm{C}$-glycine uptake by herring eggs in relation to incubation time. The experiment was carried out $135 \mathrm{~h}$ after fertilization, when the heart beat started. Standard deviations refer to a sample number of $n=4$

of these non-saturable entries were calculated from the slope of the linear portion of the uptake curve (apparent diffusion rate), amounting to 0.43 (glycine) and 0.46 (AIB) pmoles egg-1 $\mathrm{h}^{-1}$ per $\mu \mathrm{M}$ exogenous amino acid. The saturable components of the uptake curves $(C=$ glycine and $F=A I B)$ were obtained after correction of curves $\mathrm{B}$ and $\mathrm{E}$ for apparent diffusion. Maximum uptake rates $\left(\mathrm{v}_{\max }\right)$ amount to 48 pmoles $\operatorname{egg}^{-1} \mathrm{~h}^{-1}$ (glycine) and 65 pmoles egg-1 $\mathrm{h}^{-1}$ (AIB). Transport constants $\left(\mathrm{K}_{t}\right)$ - obtained by plotting the reciprocal of uptake velocity against the reciprocal of concentration (Lineweaver-Burk plot) - amount to $6.5 \mu \mathrm{M}$ (glycine) and $9.0 \mu \mathrm{M}$ (AIB).

In addition, absorptive capacities of herring eggs were compared to those of the invertebrate $E$, albidus. ${ }^{14} \mathrm{C}$-glycine and ${ }^{14} \mathrm{C}$ - $\mathrm{AIB}$ absorption rates by the oligochaete annelid Enchytraeus albidus were inserted in Figure 3. Glycine uptake in E. albidus (D) (Siebers, 1976) proceeds about six times faster than in herring eggs, while uptake of AIB (G) is of the same order of magnitude. The differences in kinetic data are remark- 

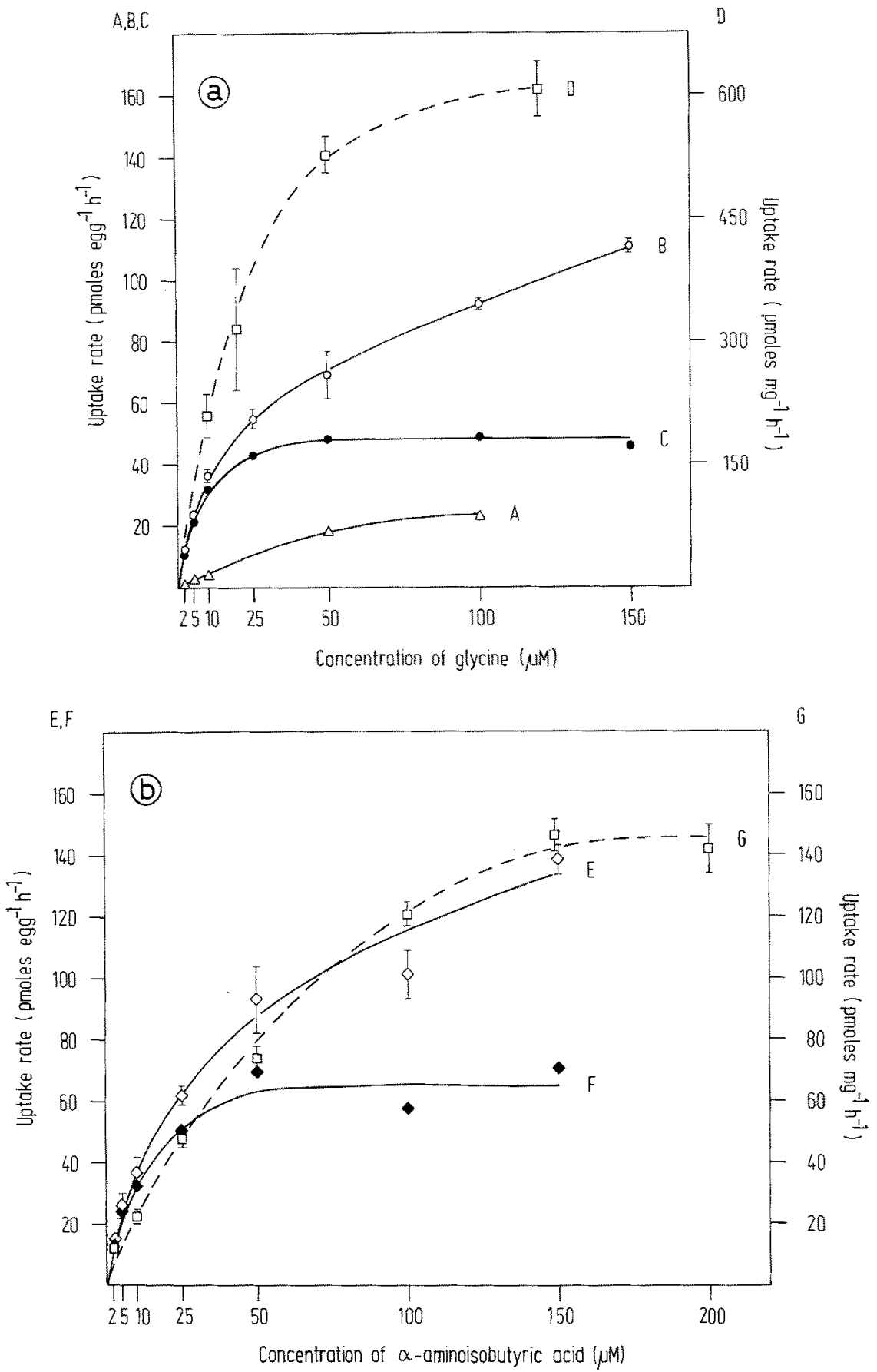

Fig. 3: Concentration-dependent absorption of glycine and AIB by herring eggs and the oligochaete Enchytraeus albidus at $15{ }^{\circ} \mathrm{C}$ and $20 \%$ S. (a) A, B, C: glycine uptake by herring eggs $5 \mathrm{~h}(\mathrm{~A})$ and $155 \mathrm{~h}$ (B) after fertilization. Curve $C$ shows the saturable component. $D$ : glycine absorption by $E$. albidus. (b) E, F: AIB uptake by herring eggs $155 \mathrm{~h}$ after fertilization (E) with the saturable component (F). G: AIB absorption by E. albidus. Vertical bars represent standard deviations ( $\mathrm{n}=4$ for herring eggs and $\mathrm{n}=6$ for $E$. albidus) 
able: $\mathrm{v}_{\max }$-values obtained for amino-acid uptake by E. albidus amount to 700 pmoles $\mathrm{mg}^{-1} \mathrm{~h}^{-1}$ (glycine) and 150 pmoles $\mathrm{mg}^{-1} \mathrm{~h}^{-1}$ (AIB), and $\mathrm{K}_{\mathrm{t}}$-values amount to $20 \mu \mathrm{M}$ (glycine) and $50 \mu \mathrm{M}$ (AIB). Both $\mathrm{K}_{t}$ and $v_{\max }$ for herring eggs are much smaller than for E. albidus. Stephens (1975) reported net glycine uptake for two polychaete species well in the range of the unidirectional glycine influx rates presented for $E$. albidus. The tendency of low $\mathrm{K}_{\mathrm{t}^{-}}$and $\mathrm{v}_{\max }$-values in epibenthic and pelagic organisms and higher values in infaunal species (Sepers, 1977) may reflect adaptations of the uptake systems to existing amino-acid concentrations. These are much higher in interstitial waters than in pelagic areas (Stephens, 1975; Sepers, 1977).

Table 1

Effect of $100 \mu \mathrm{M}$ of charged and uncharged amino acids on ${ }^{14} \mathrm{C}$-glycine absorption by herring eggs from $10 \mu \mathrm{M}$ solution. $s=$ standard deviation, referring to $n=4$ in controls and $n=3$ in test media; uptake rates in test media relative to controls are regarded highly significant $(*)$,

if $\mathrm{p}<0.003$ and significant $(*)$, if $0.01>\mathrm{p}>0.003$ and insignificant (n.s.), if $\mathrm{p}>0.01$

\begin{tabular}{|lcc|}
\hline Added amino acid & $\begin{array}{c}{ }^{14} \mathrm{C} \text {-glycine uptake } \pm s \\
\left(\text { pmoles egg }-1 \mathrm{~h}^{-1} \text { ), }\right. \\
\text { level of significance }\end{array}$ & Percentage \\
\hline Controls & $66.0 \pm 5.4$ & 100 \\
L-alanine & $13.0 \pm \pm .5 *$ & 19.7 \\
L-valine & $32.6 \pm 3.6 \%$ & 49.4 \\
L-aspartic acid & $49.7 \pm 7.1$ n.s. & 76.3 \\
L-arginine & $50.4 \pm 1.8^{*}$ & \\
\hline
\end{tabular}

In two experiments herring eggs were treated with streptomycin sulphate (20 $\left.\mathrm{mg}^{-1}\right)$ and penicillin $\left(20 \mathrm{mg}^{-1}\right)$ for $4 \mathrm{~h}$ and $24 \mathrm{~h}$, in order to test whether bacterial growth on the egg membrane influences the measured glycine absorption. The employed concentrations of antibiotics have been proven to reduce mortality due to bacterial activity in developing garpike eggs, Belone belone, from about $30 \%$ to negligible values (Rosenthal \& Fonds, 1973). When eggs (eyes grey) were treated with antibiotics for $4 \mathrm{~h}$, glycine uptake from $2 \mu \mathrm{M}$ solution decreased insignificantly by

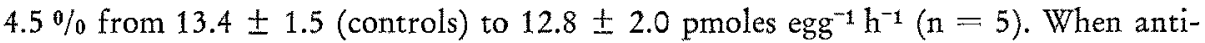
biotics were applied for $24 \mathrm{~h}$ (embryos were nearing the end of the eye-pigmentation stage) glycine uptake from $10 \mu \mathrm{M}$ solution decreased insignificantly by $19 \%$ from $66.0 \pm 5.4$ (controls) to $53.3 \pm 4.4$ pmoles $\mathrm{egg}^{-1} \mathrm{~h}^{-1}(\mathrm{n}=4)$. The results reported are not quite conclusive, but confirm that bacterial growth on the egg surface has, if any, only a minor effect on glycine absorption by herring eggs.

Amino-acid absorption capacities of herring eggs reached $13.3 \pm 2.2$ pmoles of glycine $\mathrm{egg}^{-1} \mathrm{~h}^{-1}$ and $14.4 \pm 1.5$ pmoles of AIB egg ${ }^{-1} \mathrm{~h}^{-1}$ from $2 \mu \mathrm{M}$ solutions at beginning eye pigmentation (Fig. 3). Comparable data were presented by Ahearn \& Townsley (1975) for the apodous sea cucumber, Chiridota rigida, which was shown to absorb ${ }^{14} \mathrm{C}$-glycine at a rate of 14.4 pmoles $\mathrm{mg}^{-1} \mathrm{~h}^{-1}$ from an external concentration of $1 \mu \mathrm{M}$. This comparison is based on the assumption that the wet weight of one herring egg approximates $1 \mathrm{mg}$. Scyphistomae of the coelenterate Aurelia aurita take up ${ }^{14} \mathrm{C}$-glycine from $0.8 \mu \mathrm{M}$ solution $\left(15^{\circ} \mathrm{C}\right.$ ) at rates between 300 and 400 pmoles $\mathrm{mg}^{-1}$ dry weight $\mathrm{h}^{-1}$ (Shick, 1975), depending on their nutritional state. With respect to the 
dry weight calculation basis these values are in the range of results presented for herring eggs.

\section{Specifity of glycine $t r a n s p o r t$}

Specificities of amino-acid transporting membranes in relation to the charge of the molecule first became known about three decades ago (Christensen, 1975). Almost independent from cell type, distinct mediations of neutral, basic, and acidic amino acids are observable. From the available set of investigations we chose the inhibition of glycine uptake from $10 \mu \mathrm{M}$ solution - close to the $\mathrm{K}_{\mathrm{t}}$ of glycine influx - by $100 \mu \mathrm{M}$ of L-alanine and L-valine (neutral amino acids), L-aspartic acid (acidic), and L-arginine (basic). As shown in Table 1 , the greatest inhibition of ${ }^{14} \mathrm{C}$-glycine influx $(80.3 \%)$ occurs in the presence of $\mathrm{L}$-alanine, while in the presence of $\mathrm{L}$-valine a reduction by $50.6 \%$ is obtained. Glycine uptake rates are reduced to a much smaller extent after addition of the two charged amino acids L-aspartic acid and L-arginine to the incubation medium. It is not known whether the inhibiting amino acids are taken up at all by herring eggs. However, a specificity of glycine transport for neutral amino acids may also be valid for such a complex structure as a developing herring egg.

\section{DISCUSSION}

Uptake of ${ }^{14} \mathrm{C}$-glycine by herring eggs does not necessarily represent net uptake, but demonstrates unidirectional ${ }^{14} \mathrm{C}$-glycine influx. The measured uptake values are certainly composed of influx and effiux events. By utilization of the amino acid analogue, AIB, however, true net flux data are obtained, since this amino acid has never been described to be metabolically utilized or incorporated into substances of higher molecular weight. Future experiments will be concerned with the direct analysis of net influxes of naturally occurring amino acids, including distribution of ${ }^{14} \mathrm{C}-1$ abel within the egg. The good agreement of the concentration-dependent ${ }^{14} \mathrm{C}$-influx curves for glycine and AIB (Fig. 3) provides some evidence that glycine transport may also result in positive net influxes.

$\mathrm{O}_{2}$ uptake and glycine absorption similarly increase with ontogenetic age (Fig. 1), suggesting that amino-acid absorption capacities may be associated with increasing embryonic activity. A similar tendency seems to be valid for sea urchin embryos. Uptake of ${ }^{14} \mathrm{C}$-leucine by developing sea urchin eggs increases from fertilization to hatch with a small retardation between the first metaphase and the subsequent cleavage (Fry \& Gross, 1970).

The question whether herring eggs obtain a significant nutritional profit from uptake of amino acids cannot be answered without knowledge of net influx data for natural amino acids. But even if the results obtained represented net influx and no exchange diffusion occurred, uptake rates would be too low to provide more than a few percent of the energy requirements equivalent to the egg's oxygen consumption: calculations are based on the assumption that combustion of $1 \mu \mathrm{g}$ amino acids (protein) 
requires $0.93 \mu \mathrm{l} \mathrm{O}$, of a medium molecular weight of about $100 \mathrm{~g} \mathrm{~mole}^{-1}$ of naturally occurring amino acids, an amino-acid uptake rate of about 15 pmoles (demonstrated for glycine and AIB) $\mathrm{egg}^{-1} \mathrm{~h}^{-1}$ from $2 \mu \mathrm{M}$ solution at $15^{\circ} \mathrm{C}$ and $20 \% \mathrm{~S}$ (see p. 469) at the beginning of the eye-pigmentation stage (Fig. 3). At this stage $\mathrm{O}_{2}$ uptake amounts to about $130 \mathrm{nl} \mathrm{egg}^{-1} \mathrm{~h}^{-1}$ at $14^{\circ} \mathrm{C}$ and $15 \% \mathrm{~S}$ (Stelzer et al., 1971). The percentage of energy requirement equivalent to $O_{\mathrm{Z}}$ uptake amounts to $15 \cdot 10^{2} \cdot 0.93 \cdot 10^{2} \cdot 10^{-3} \cdot 130^{-1}$ $=1.1 \%$. We therefore conclude that herring eggs scarcely obtain nutritional profit from absorption of dissolved amino acids in their natural spawning areas, but exclusively depend on the energy content stored as chemical energy in the yolk.

Acknowledgements. The authors would like to thank Mrs. U. Ehlers, Mrs. G. Fürstenberg, and Miss J. Klinckmann for skilful technical assistance.

\section{LITERATURE CITED}

Ahearn, G. A. \& Townsley, S. J., 1975. Integumentary amino acid transport and metabolism in the apodous sea cucumber, Chiridota rigida. J. exp. Biol. 62, 733-752.

Christensen, H. N., 1975. Biological transport. Benjamin, Reading, Mass. 514 pp.

Fry, B. J. \& Gross, P. R., 1970. Patterns and rates of protein synthesis in sea urchin embryos. I. Uptake and incorporation of amino acids during the first cleavage cycle. Devl. Biol. 21, 105-124.

Jørgensen, C. B., 1976. August Pütter, August Krogh, and modern ideas on the use of dissolved organic matter in aquatic environments. Biol. Rev. 51, 291-328.

North, B. B., 1975. Primary amines in California coastal waters: utilization by phytoplankton. Limnol. Oceanogr. 20, 20-27.

Rosenthal, H., 1968. Schwimmverhalten und Schwimmgeschwindigkeit bei den Larven des Herings Clupea barengus. Helgoländer wiss. Meeresunters. 18, 453-486.

- \& Stelzer, R., 1970. Wirkungen von 2,4- und 2,5-Dinitrophenol auf die Embryonalentwicklung des Herings Clupea barengus. Mar. Biol. 5, 325-336.

- \& Fonds, M., 1973. Biological observations during rearing experiments with the garfish Belone belone. Mar. Biol. 21, 203-218.

Sepers, A. B. J., 1977. The utilization of dissolved organic compounds in aquatic environments. Hydrobiologia 52, 39-54.

Shick, J. M., 1975. Uptake and utilization of dissolved glycine by Aurelia aurita Scyphistomae: temperature effects on the uptake process; nutritional role of dissolved amino acids. Biol. Bull. mar. biol. Lab., Woods Hole 148, 117-140.

Siebers, D., 1976. Absorption of neutral and basic amino acids across the body surface of two annelid species. Helgoländer wiss. Meeresunters. 28, 456-466.

— \& Bulnheim, H.-P., 1976. Salzgehaltsabhängigkeit der Aufnahme gelöster Aminosäuren bei dem Oligochaeten Enchytraeus albidus. Verh. dt. zool. Ges., 69, 212.

Stelzer, R., Rosenthal, H. \& Siebers, D., 1971. Einfluß von 2,4-Dinitrophenol auf die Atmung und die Konzentration einiger Metabolite bei Embryonen des Herings Clupea barengus. Mar. Biol. 11, 369-378.

Stephens, G. C., 1975. Uptake of naturally occurring primary amines by marine annelids. Biol. Bull. mar. biol. Lab., Woods Hole 149, 397-407.

First author's address: Dr. D. Siebers

Biologische Anstalt Helgoland (Zentrale)

Palmaille 9

D-2000 Hamburg 50

Federal Republic of Germany 